


\section{Cormac McCarthy}

\section{MANCHESTER 1824}

Manchester University Press 


\section{CONTEMPORARY AMERICAN AND CANADIAN WRITERS}

Series editors

Nahem Yousaf and Sharon Monteith

Also available

Crossing borders and queering citizenship: Civic reading practice in contemporary American and Canadian writing ZALFA FEGHALI

The quiet contemporary American novel RACHEL SYKES

Sara Paretsky: Detective fiction as trauma literature CYNTHIA S. HAMILTON

Making home: Orphanhood, kinship, and cultural memory in contemporary American novels MARIA HOLMGREN TROY, ELIZABETH KELLA, HELENA WAHLSTROM

Thomas Pynchon SIMON MALPAS AND ANDREW TAYLOR

Jonathan Lethem JAMES PEACOCK

Mark Z Danielewski EDITED By JOE BRAY AND ALISON GIBBONS

Louise Erdrich DAVID STIRRUP

Passing into the present: contemporary American fiction of racial and gender passing SINÉAD MOYNIHAN

Paul Auster MARK BROWN

Douglas Coupland ANDREW TATE

Philip Roth DAVID BRAUNER 


\title{
Cormac McCarthy
}

\section{A complexity theory of literature}

\author{
Lydia R. Cooper
}

Manchester University Press 
Copyright $\odot$ Lydia R. Cooper 2021

The right of Lydia R. Cooper to be identified as the author of this work has been asserted by them in accordance with the Copyright, Designs and Patents Act 1988.

Published by Manchester University Press

Altrincham Street, Manchester M1 7JA

www.manchesteruniversitypress.co.uk

British Library Cataloguing-in-Publication Data A catalogue record for this book is available from the British Library

ISBN 9781526148582 hardback

First published 2021

The publisher has no responsibility for the persistence or accuracy of URLs for any external or third-party internet websites referred to in this book, and does not guarantee that any content on such websites is, or will remain, accurate or appropriate.

Cover: Zuni Pueblo, New Mexico

Typeset by

Servis Filmsetting Ltd, Stockport, Cheshire 